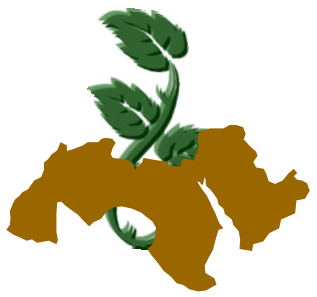

Arab Univ.

\title{
EFFECT OF SOME ORGANIC AND BIOFERTILIZER TREATMENTS ON MINIMIZING MINERAL NITROGEN FERTILIZATION OF WASHINGTON NAVEL ORANGE TREES
}

\author{
Eman, A.A. Abd El-Moneim ${ }^{1}$; A.S.E. Abd-Allah ${ }^{1}$ and Sanaa, S. Ebeed ${ }^{2}$ \\ 1- Horticulture Crops Technology, National Research Center, Cairo \\ 2- Horticultural Research Institute, Agricultural Research Center, Cairo
}

Keywords: Washington Navel orange, Organic fertilizer, Biofertilizer, Yield, Fruit quality, Nitrate and nitrite content

\footnotetext{
ABSTRACT

The present investigation was conducted during two successive seasons to study the effect of replacing mineral nitrogen fertilization by organic nitrogen source with or without biofertilizer addition on Washington Navel orange trees, under sandy soil conditions. Percentages of 100,50 , and $25 \%$ of mineral nitrogen were replaced by 50,75 and $100 \%$ of organic nitrogen with or with out Saccharomyces cerevisae (yeast) as a source of biofertilizer. Treatment of $50 \%$ mineral $\mathrm{N}+50 \%$ organic $\mathrm{N}$ and treatment of $100 \%$ organic $\mathrm{N}$ as well as the control (100\% mineral nitrogen) recorded the higher values of $\mathrm{N}$ in the leaves especially in the second season. Treatments included organic fertilization raised $\mathrm{N} \%$ in the second season. Phosphorus percentage in the leaves did not differ by treatments in both seasons. All treatments enhanced $\mathrm{K}$ content in the leaves especially in the second season. On the other hand, adding biofertilizer treatments improved $\mathrm{N}, \mathrm{P}$ and $\mathrm{K}$ content in the leaves especially in the presence of mineral $\mathrm{N}$. As for yield per tree, all treatments increased number of fruits and yield weight/tree than the control especially in the second season. The effect of treatments on fruit quality was clearly shown in the first season, since most of the treatments improved fruit quality parameters especially treatment of $50 \%$ mineral $\mathrm{N}$ $+50 \%$ organic $\mathrm{N}$ fertilizers. On the other side, treatments containing organic or bio-fertilizer reduced nitrogen, nitrate and nitrite values in fruit juice comparing with the control $(100 \%$ mineral $\mathrm{N}$ fertilizer).
}

\section{INTRODUCTION}

Citrus is the first fruit crop in Egypt. Washington Navel orange cultivar has a great importance either for the local market or export needs. Economically, it ranks the top among orange cvs., since it occupies 124271 feddan (one feddan $=4200 \mathrm{~m}^{2}$ ) with fruiting area reached 110050 feddan, producing 1050462 tons according to Ministry of Agriculture and Land Reclamation statistics, 2004. This means that the yield is still low and attained about 9.55 tons per feddan. Increasing productivity and improving fruit quality are the main targets of many specialists. There is a general agreement that several factors affect productivity and fruit quality of orange trees. One of the important factors plays a vital role, in this concern, is nitrogen fertilization which considered as agent of accumulative harmful residues like nitrate and nitrite in fruit juice, Montasser et al (2003).

Thus, a great attention is focused on minimizing the intensive amounts of mineral nitrogen fertilization especially under sandy soils conditions which are naturally poor either in nutrient elements or organic matter through using alternative organic $\mathrm{N}$ fertilization as well as using biofertilizer which had illustrated greater nutrient use efficiencies of crops and in particular fruit crops when such inoculates were added to either organic matter or soil, Sangakkora and Weerakera, 1999 (as quoted by Saleh et al 2006).

Accordingly, the present investigation was planned and conducted to evaluate the effect of combined application of mineral $\mathrm{N}$ and Farmyard manure (FYM) as organic $\mathrm{N}$ fertilizer with or without addition of Saccharomyces cerevisae (yeast) as a source of biofertilizer on leaf mineral content, yield and fruit quality as well as nitrate and nitrite 
content in fruit juice of Washington Navel orange trees grown under sandy soil conditions.

\section{MATERIALS AND METHODS}

The present investigation was conducted during two successive seasons 2004 and 2005 in a private citrus orchard located at El-Sadat district, Menofiya Governorate, Egypt on 15 years old
Washington Navel orange trees. The trees were budded on Volkamer lemon ( $C$. volkameriana) rootstock and planted at $5 \times 5$ meters apart under drip irrigation system. The texture of the soil is sandy as the result of soil analysis (Table 1). Also, farmyard manure analysis according to Wilde et al (1985) are given in Table (2). The selected trees were nearly uniform in vigor as possible.

\section{Table 1. Analytical properties of the soil at the experimental location}

\section{a- Mechanical analysis}

\begin{tabular}{|c|c|c|c|}
\hline Sand (\%) & Silt (\%) & Clay (\%) & Texture \\
\hline 90 & 5 & 5 & Sandy \\
\hline
\end{tabular}

\section{b- Chemical analysis}

\begin{tabular}{|c|c|c|c|c|c|c|c|c|c|c|c|}
\hline \multirow{2}{*}{$\begin{array}{c}\mathrm{pH} \\
(1: 2.5)\end{array}$} & \multirow{2}{*}{$\begin{array}{c}\text { EC } \\
\text { dsm }^{-1} \\
(1: 1)\end{array}$} & \multirow{2}{*}{$\begin{array}{c}\mathrm{CaCO}_{3} \\
(\%)\end{array}$} & \multirow{2}{*}{$\begin{array}{c}\mathrm{N} \\
\mathrm{ppm}\end{array}$} & \multicolumn{4}{|c|}{$\begin{array}{l}\text { Soluble cations } \\
\qquad(\mathrm{meq} / \mathrm{l})\end{array}$} & \multicolumn{4}{|c|}{$\begin{array}{l}\text { Soluble anions } \\
\qquad(\mathrm{meq} / \mathrm{l})\end{array}$} \\
\hline & & & & $\mathrm{K}$ & $\mathrm{Na}$ & $\mathrm{Ca}$ & $\mathrm{Mg}$ & $\mathrm{Cl}$ & $\mathrm{SO}_{4}$ & $\mathrm{HCO}_{3}$ & $\mathrm{CO}_{3}$ \\
\hline 8.2 & 1.5 & 5.5 & traces & 0.57 & 9.18 & 2.65 & 2.40 & 5.3 & 5.65 & 3.85 & --- \\
\hline
\end{tabular}

Table 2. Some physical and chemical characteristics of the used Farmyard manure

\begin{tabular}{|l|c|}
\hline \multicolumn{1}{|c|}{ Parameter } & Values \\
\hline Cubic meter weight $(\mathrm{kg})$ & 650 \\
Moisture \% & 35 \\
Organic matter & 23.6 \\
Organic carbon & 21.4 \\
$\mathrm{pH}(1: 10)$ & 8.7 \\
EC (mmohs/cm) & 5.7 \\
C/N ratio & 24.0 \\
Total N \% & 0.89 \\
Total P \% & 0.32 \\
Total K \% & 0.92 \\
Total Ca \% & 1.82 \\
Total Mg \% & 0.96 \\
Total Fe ppm & 1500 \\
Total Mn ppm & 420 \\
Total Zn ppm & 53 \\
\hline
\end{tabular}

The experiment included seven treatments as follows:

1- $100 \%$ MNF (control).

2- $50 \% \mathrm{MNF}+50 \% \mathrm{ONF}$

3- $50 \% \mathrm{MNF}+50 \% \mathrm{ONF}+\mathrm{BF}$

4- $25 \% \mathrm{MNF}+75 \%$ ONF

5- $25 \% \mathrm{MNF}+75 \% \mathrm{ONF}+\mathrm{BF}$

6- $100 \%$ ONF

7- $100 \%$ ONF+ BF

\section{Where}

MNF = Mineral N fertilization.

$\mathrm{ONF}=$ Organic $\mathrm{N}$ fertilization .

$\mathrm{BF}=$ Biofertilization with Yeast (Saccharomyces cerevisae).

The control trees received the common amount of nitrogen fertilizer (1000 gm N/tree/year) as ammonium sulphate $(20.5 \% \mathrm{~N})$. Organic $\mathrm{N}$ fertilizer was added as Farmyard manure (FYM) $(0.89 \% \mathrm{~N})$ at rate of $56 \mathrm{~kg} /$ tree. Yeast (Saccharomyces cerevisae) (BF) isolated and identified by Gomaa (1995) were grown to the late exponential phase in a sterilized medium prepared in Microbiology De- 
partment, National Research Centre. The resultant cultures contained $6.2 \times 105 \mathrm{cell} / \mathrm{ml}$ for biofertilizer (BF) which added at rate of two liters per tree. Organic and biofertilizer were side dressed in a band of $100 \mathrm{~cm}$ wide on both sides of the tree at one meter apart from the tree trunk in the direction of tree row and mixed with the surface of $20 \mathrm{~cm}$ of soil in late January of each season while mineral $\mathrm{N}$ fertilization was added at three equal doses on March, May and August. Each treatment was replicated three times on one tree plots and the randomized complete block design was arranged.

The chosen trees received the normal fertilization program including the addition of $100 \mathrm{Kg}$ per feddan calcium super phosphate $\left(15.5 \% \mathrm{P}_{2} \mathrm{O}_{5}\right)$ in late January and $600 \mathrm{gm}$ potassium sulphate (48$52 \% \mathrm{~K}_{2} \mathrm{O}$ ) /tree/year in March and August. The other horticultural practices were the same for all trees under investigation.

To determine leaf mineral content, about forty leaves were taken in late August in each season from tagged non-fruiting and non-flushing spring growth cycle according to Jones and Embleton (1960). Leaf samples were washed with tap water, then with distilled water and dried at $105^{\circ} \mathrm{C}$ till a constant weight, finally ground and digested. The digested solution was used to determine $\mathrm{N}, \mathrm{P}$ and $\mathrm{K}$ content as percentage on dry weight basis according to Cottenie et al (1982).

At the harvesting time (late December of each season), yield per tree was determined as number and weight of fruits $(\mathrm{kg}) /$ tree.

For fruit quality determinations, samples of ten fruits were taken from each replicate to determine the physical and chemical properties as the methods described in A.O.A.C. (1985).

A sample of $10 \mathrm{ml}$ of fruit juice was taken from each replicate to determine nitrogen, phosphorus, potassium, nitrate and nitrite content in fruit juice. $\mathrm{N}, \mathrm{P}$ and $\mathrm{K} \%$ were determined using the same methods described in leaf mineral content, while $\mathrm{NO}_{3}{ }^{-}$and $\mathrm{NO}_{2}{ }^{-}$content were determined according to the methods outlined by Sen and Donaldson (1978).

The data were subjected to analysis of variance and Duncan's multiple range test was used to differentiate means, Duncan (1955).

\section{RESULTS AND DISCUSSION}

\section{Leaf mineral content}

Data in Table (3) show that leaf mineral content was significantly affected by different treatments in both seasons.
As for nitrogen content in the leaves in the first season, it is clear that $100 \%$ mineral nitrogen fertilization treatment gave the highest value of $\mathrm{N} \%$ compared with the other treatments. In other word, reducing mineral nitrogen amount decreased nitrogen content in the leaves. While in the second season, organic fertilization treatments raised $\mathrm{N} \%$ in the leaves compared with the first season. However, treatments 3, 6 increased $\mathrm{N}$ value and did not differ statistically than the control $(100 \%$ mineral $N$ ) which gave the higher $\mathrm{N}$ content.

Regarding $P$ content in the leaves, no significant differences were detected between treatments in both seasons.

Concerning $\mathrm{K} \%$ in the leaves, the control and treatment 5 gave the higher values of $\mathrm{K} \% \mathrm{com}$ pared with other treatments in the first season, while in the second one, all treatments enhanced $\mathrm{K}$ content in the leaves and no differences were detected between them except treatments 4 and 5 which gave the lower values.

On the other hand, it is observed that adding biofertilizer treatments raised $\mathrm{N}, \mathrm{P}$ and $\mathrm{K}$ content in the leaves especially with the treatments included mineral $\mathrm{N}$.

The obtained results are in harmony with the findings by Abd El-Migeed et al (2007) on orange, Saleh et al (2006) on grapevine and Fayed (2005) on apple since the chemical fertilizer gave the highest leaf $\mathrm{N}$ and $\mathrm{K}$ contents compared with organic fertilization with or without biofertilizers.

\section{Yield}

As for yield, Table (4) showed that in both studied seasons, all treatments increased number of fruits/tree than the control. However, in the first season, treatment 3 gave the highest number of fruits followed by treatment 2 and 5 . In the second season, treatment 4 gave the highest value, while $100 \%$ mineral $\mathrm{N}$ fertilization (control) gave the lowest one.

Regarding yield weight $(\mathrm{kg})$ in the first season, treatment 3 gave the highest yield compared with other treatments including the control. While in the second season, the obtained results seemed to took the same trend of No. of fruits/tree. Average yield of the two seasons indicated that, treatment 3 gave the highest yield followed in a decreasing order by treatment 4,5 and 2 without significant differences between them.

Concerning average fruit weight, in the first season all treatments gave the same statistical results and no differences were detected between 
Table 3. Leaf mineral content of Washington Navel orange trees as affected by mineral and organic nitrogen fertilization with some biofertilizers during 2004 and 2005 seasons

\begin{tabular}{|llcccccc|}
\hline \multirow{2}{*}{ No. } & \multirow{2}{*}{ Treatments } & \multicolumn{2}{c}{ N\% } & \multicolumn{2}{c}{$\mathrm{P} \%$} & \multicolumn{2}{c|}{$\mathrm{K} \%$} \\
\cline { 2 - 7 } & & 2004 & 2005 & 2004 & 2005 & 2004 & 2005 \\
\hline 1 & $100 \%$ MNF (control). & $1.47 \mathrm{a}$ & $1.50 \mathrm{a}$ & 0.140 & 0.137 & $0.97 \mathrm{a}$ & $0.96 \mathrm{a}$ \\
2 & $50 \% \mathrm{MNF}+50 \% \mathrm{NF}$ & $1.30 \mathrm{~b}$ & $1.33 \mathrm{bc}$ & 0.120 & 0.120 & $0.44 \mathrm{~cd}$ & $0.94 \mathrm{a}$ \\
3 & $50 \% \mathrm{MNF}+50 \%$ ONF + BF & $1.33 \mathrm{~b}$ & $1.50 \mathrm{a}$ & 0.130 & 0.153 & $0.66 \mathrm{bc}$ & $0.70 \mathrm{abc}$ \\
4 & $25 \% \mathrm{MNF}+75 \%$ ONF & $1.23 \mathrm{c}$ & $1.30 \mathrm{bc}$ & 0.126 & 0.107 & $0.71 \mathrm{~b}$ & $0.43 \mathrm{c}$ \\
5 & $25 \% \mathrm{MNF}+75 \%$ ONF + BF & $1.30 \mathrm{~b}$ & $1.20 \mathrm{c}$ & 0.120 & 0.150 & $0.90 \mathrm{ab}$ & $0.53 \mathrm{bc}$ \\
6 & $100 \%$ ONF & $1.20 \mathrm{c}$ & $1.40 \mathrm{ab}$ & 0.140 & 0.110 & $0.45 \mathrm{~cd}$ & $0.90 \mathrm{a}$ \\
7 & $100 \%$ ONF+ BF & $1.20 \mathrm{c}$ & $1.30 \mathrm{bc}$ & 0.130 & 0.167 & $0.36 \mathrm{~d}$ & $0.78 \mathrm{ab}$ \\
\hline
\end{tabular}

Means having the same letters within a column are not significantly different at $5 \%$ level.

Table 4. Number of fruits/tree, yield weight/tree and average fruit weight of Washington Navel orange trees as affected by mineral and organic nitrogen fertilization with some biofertilizers during 2004 and 2005 seasons

\begin{tabular}{|c|c|c|c|c|c|c|c|c|}
\hline \multirow[t]{2}{*}{ No. } & \multirow{2}{*}{ Treatments } & \multicolumn{2}{|c|}{ No. fruits/tree } & \multicolumn{2}{|c|}{$\begin{array}{c}\text { Yield } \\
\text { (kg/tree) }\end{array}$} & \multirow{2}{*}{$\begin{array}{l}\text { Average } \\
\text { yield of } \\
\text { the two } \\
\text { seasons }\end{array}$} & \multicolumn{2}{|c|}{$\begin{array}{c}\text { Average fruit } \\
\text { weight } \\
\text { (gm) }\end{array}$} \\
\hline & & 2004 & 2005 & 2004 & 2005 & & 2004 & 2005 \\
\hline 1 & $100 \%$ MNF (control). & $147.0 \mathrm{~cd}$ & $140.0 c$ & $46.5 b c$ & $38.8 c$ & $42.6 c$ & $273.0 \mathrm{a}$ & 278.0 \\
\hline 2 & $50 \% \mathrm{MNF}+50 \% \mathrm{ONF}$ & 295.0ab & $226.0 \mathrm{ab}$ & $61.3 b$ & $58.8 \mathrm{ab}$ & $60.0 \mathrm{ab}$ & $206.0 \mathrm{~b}$ & 260.0 \\
\hline 3 & $50 \% \mathrm{MNF}+50 \% \mathrm{ONF}+\mathrm{BF}$ & $327.0 \mathrm{a}$ & $210.0 \mathrm{ab}$ & $88.2 a$ & 53.3abc & $70.7 a$ & 263.0ab & 260.0 \\
\hline 4 & $25 \%$ MNF $+75 \%$ ONF & $220.0 \mathrm{bcd}$ & $235.0 \mathrm{a}$ & $63.5 b$ & $65.7 a$ & $64.4 \mathrm{a}$ & $320.0 \mathrm{a}$ & 283.0 \\
\hline 5 & $25 \% \mathrm{MNF}+75 \% \mathrm{ONF}+\mathrm{BF}$ & 228.0abc & $216.0 \mathrm{ab}$ & $64.5 b$ & $58.0 \mathrm{ab}$ & $61.2 \mathrm{ab}$ & $273.0 \mathrm{a}$ & 256.0 \\
\hline 6 & $100 \%$ ONF & $143.0 d$ & 193.0abc & $38.8 \mathrm{c}$ & $50.1 \mathrm{abc}$ & $44.4 \mathrm{c}$ & $270.0 a$ & 268.0 \\
\hline 7 & $100 \% \mathrm{ONF}+\mathrm{BF}$ & $175.0 \mathrm{~cd}$ & $171.0 \mathrm{bc}$ & $51.4 \mathrm{bc}$ & $45.1 \mathrm{bc}$ & $48.2 \mathrm{bc}$ & $300.0 \mathrm{a}$ & 268.0 \\
\hline
\end{tabular}

Means having the same letters within a column are not significantly different at $5 \%$ level

them except treatment 2 which gave the lowest fruit weight, while in the second season, no significant differences were observed between treatments. On the other hand, the increment in yield weight was due to the increasing in number of fruits/tree. The obtained results are in line with Fayed (2005) and Hassan and Abou Raya (2003) on apple.

From the above results, it is observed that the increment of yield weight may be due to the improvement of fruit set, consequently increased final fruit numbers per tree. The positive effect of most organic treatments on yield as number of fruits/tree or weight $(\mathrm{kg} / \mathrm{tree})$ could be attributed to the beneficial effect of the tested materials (organic manure) on improving fruit set.

\section{Fruit quality}

Table (5) shows the effect of the studied treatments on fruit quality. In this concern, peel thickness was increased by all treatments than the control in the first season. On the contrary, all treatments reduced such parameter than the control in the second season.

Juice weight was increased by all treatments except treatment 2 which gave the lowest value. This was true in the first season, while in the second one, no significant differences were observed between the treatments.

Total soluble solids (TSS) in the fruit juice reached the maximum value with treatment 2 followed in a decreasing order by treatment 7 and 3 , 
Table 5. Some physical and chemical properties of Washington Navel orange trees as affected by mineral and organic nitrogen fertilization with some biofertilizers during 2004 and 2005 seasons

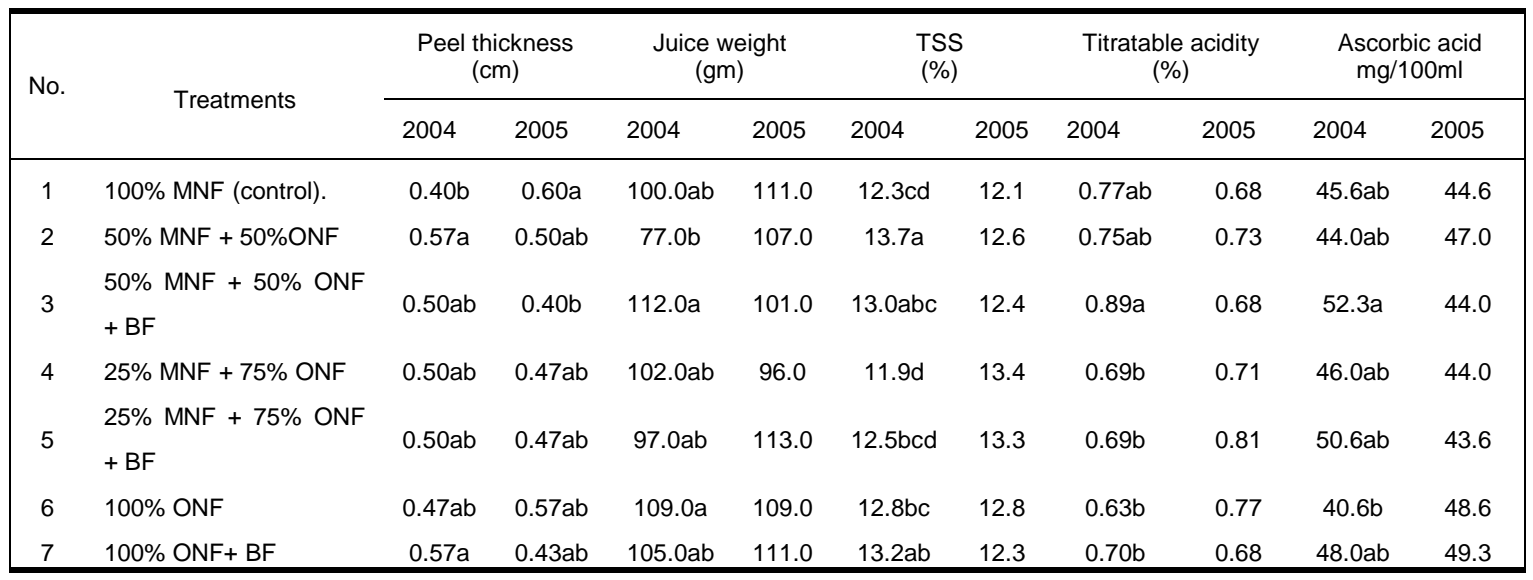

Means having the same letters within a column are not significantly different at $5 \%$ level.

Table 6. Nitrogen, nitrite and nitrate contents $(\mathrm{ppm})$ in fruit juice of Washington Navel orange trees as affected by mineral and organic nitrogen fertilization with some biofertilizers during 2004 and 2005 seasons

\begin{tabular}{|clllllll|}
\hline \multirow{2}{*}{ No. } & \multirow{2}{*}{ Treatments } & \multicolumn{2}{c}{$\mathrm{N}(\mathrm{ppm})$} & \multicolumn{2}{c|}{$\mathrm{NO}_{2}(\mathrm{ppm})$} & \multicolumn{2}{c|}{$\mathrm{NO}_{3}$ (ppm) } \\
\cline { 3 - 7 } & & 2004 & 2005 & 2004 & 2005 & 2004 & 2005 \\
\hline 1 & $100 \%$ MNF (control). & $1624 \mathrm{a}$ & $1297 \mathrm{a}$ & $2.56 \mathrm{a}$ & $2.50 \mathrm{a}$ & $47.2 \mathrm{a}$ & $46.5 \mathrm{a}$ \\
2 & $50 \% \mathrm{MNF}+50 \% \mathrm{NF}$ & $1094 \mathrm{~b}$ & $573 \mathrm{e}$ & $2.10 \mathrm{~b}$ & $1.86 \mathrm{bc}$ & $20.7 \mathrm{c}$ & $33.4 \mathrm{~b}$ \\
3 & $50 \%$ MNF + 50\% ONF + BF & $803 \mathrm{bc}$ & $587 \mathrm{be}$ & $1.85 \mathrm{~b}$ & $2.10 \mathrm{~b}$ & $27.5 \mathrm{~b}$ & $29.3 \mathrm{bc}$ \\
4 & $25 \%$ MNF + 75\% ONF & $870 \mathrm{~b}$ & $751 \mathrm{~cd}$ & $2.03 \mathrm{~b}$ & $1.56 \mathrm{c}$ & $28.4 \mathrm{~b}$ & $26.3 \mathrm{c}$ \\
5 & $25 \% \mathrm{MNF}+75 \%$ ONF + BF & $719 \mathrm{bc}$ & $904 \mathrm{bc}$ & $1.80 \mathrm{~b}$ & $1.73 \mathrm{bc}$ & $29.3 \mathrm{~b}$ & $25.1 \mathrm{c}$ \\
6 & $100 \%$ ONF & $898 \mathrm{~b}$ & $920 \mathrm{bc}$ & $1.83 \mathrm{~b}$ & $1.86 \mathrm{bc}$ & $31.7 \mathrm{~b}$ & $29.9 \mathrm{bc}$ \\
7 & $100 \%$ ONF+ BF & $441 \mathrm{c}$ & $931 \mathrm{~b}$ & $1.90 \mathrm{~b}$ & $1.83 \mathrm{bc}$ & $27.5 \mathrm{~b}$ & $27.9 \mathrm{c}$ \\
\hline
\end{tabular}

Means having the same letters within a column are not significantly different at $5 \%$ level.

while, it reached the lowest value with treatment 4. This was true in the first season only, while in the second one, no significant differences were detected between the studied treatments.

Titratable acidity percentage in the first season, recorded the highest value with treatment 3 followed in a decreasing order by treatment 1 and 2 . In the second season, no significant differences between all treatments were observed.

As for ascorbic acid (vitamin C) content in the fruit juice, treatment 3 gave the highest value and no differences were detected between it and the other treatments, except treatment 6 which gave the lowest value in the first season. In the second season, no significant differences were observed between all the studied treatments.

The obtained results are in line with the findings by Moustafa (2002) on Washington Navel orange, Akl et al (1997) on grapevine and Salama (2002) on Balady mandarin.

Nitrogen, nitrate and nitrite content in the fruit juice are shown in Table 6 , since all treatments containing organic or bio-fertilizer reduced nitrogen, nitrate and nitrite values in fruit juice comparing with the control (100\% mineral $\mathrm{N}$ fertilizer).

As shown in Table (6), results revealed that nitrate and nitrite contents in fruit juice were significantly decreased by different treatments in the two 
studied seasons comparing with $100 \%$ mineral N (control). This means that replacing nitrogen fertilization through using organic form (FYM) instead of mineral $\mathrm{N}$ form had a beneficial effect on reducing nitrate and nitrite contents in fruit juice. In this respect, mineral nitrogen fertilization easily forms nitrate, whereas organic fertilizers slowly form nitrate, Ibraheem (1994).

The beneficial effect of organic and biofertilizer on reducing nitrate and nitrite contents in fruit juice is supported by those obtained on grapevine by Farag (2006) and Rizk-Alla (2006).

From the abovementioned results, it could be concluded that using $50 \%$ mineral $\mathrm{N}+50 \%$ organic $\mathrm{N}+$ biofertilizer is the promising treatment to improve both fruit yield and quality of Washington Navel orange trees.

\section{REFERENCES}

Abd El-Migeed, M.M.M.; M.M.S. Saleh and E.A.M. Mostafa, (2007). The beneficial effect of minimizing mineral nitrogen fertilization on Washington Navel orange trees by using organic and biofertilizers. World J. of Agricultural Science, 3(1): 80-85.

Akl, A.M.; F.F. Ahmed; F.M. El-Morsy and M.A. Ragab, (1997). The beneficial effects of biofertilizers on Red Roomy grapevines (Vitis vinifera, L.). 2The effect on berry set, yield and quality of berries. Annals of Agric. Sci., Moshtohor, 35: 497-502, Egypt.

A.O.A.C., (1985). Official Methods of Analysis, A.O.A.C. $14^{\text {th }}$ Ed., pp. 494-510, Benjamin Franklin Station Washington DC, USA..

Cottenie, A.; M. Verloo; L. Kiekens; G. Velgle and R. Amerlynuck, (1982). Chemical Analysis of Plant and Soil, pp. 43- 51. Laboratory of Analytical and Agroch. State Univ.of Belgium, Gent.

Duncan, D.B. (1955). Multiple range and multiple "F" tests. Biometrics, 11: 1-42.

Farag, S.G. (2006). Minimizing Mineral Fertilizers in Grapevine Farms to Reduce the Chemical Residuals in Grapes. pp. 42-104. M.Sc. Thesis, Institute of Environmental Studies \& Research, Ain Shams University, Egypt.

Fayed, T.A. (2005). Effect of some organic manures and biofrtilizers on Anna apple trees. I- Vegetative growth and leaf chemical constituents. Egypt. J. Appl. Sci., 20: 159-175.
Gomaa, A.M. (1995). Response of Certain Vegetable Crops to Biofertilization. pp. 39-97. Ph.D. Thesis, Fac. Agric. Cairo Univ., Egypt.

Hassan, H.S.A. and M.S. Abou Raya, (2003). Effect of some biofertilizers on leaf mineral content, yield and fruit quality of Anna apple trees grown under Northern Sinai conditions. Egypt. J. Appl. Sci., 18: 559-574.

Ibraheem, T. (1994). Water Pollution. Part I., pp. 58-61. Science and Life Series. Egyptian Organization for Books, Cairo, Egypt,. (In Arabic).

Jones, W.W. and T.W. Embleton, (1960). Leaf analysis- nitrogen control program for oranges. Calif. Citrogr., 45 : 349- 353 (c.f. Hort. Abst. 31 : 3128).

Montasser, A.S.; N. El-Shahat; G.F. Ghobreial and M.Z. El-Wadoud, (2003). Residual effect of nitrogen fertilization on leaves and fruits of Thompson Seedless Grapes. J. Environ. Sci., 6: 465484.

Moustafa, M.H. (2002). Studies on Fertilization of Washington Navel Orange Trees. pp. 44-141. Ph.D. Dissertation, Fac. of Agric., Moshtohor, Zagazig University, Benha Branch, Egypt.

Rizk-Alla, M.S. (2006). Minimizing mineral nitrogenous fertilizers in "Flame Seedless vineyards" through the application of some biofertilizers to reduce nitrate and nitrite residues in the berries. Egypt J. Appl. Sci., 21: 246-264.

Salama, A.S.M. (2002). Response of Some Fruit Species Transplants and Trees to Organic Fertilization. pp. 65-272. Ph.D. Thesis, Fac. Agric., Moshtohor, Zagazig Univ. Benha branch, Egypt.

Saleh, M.M.S.; S. El-Ashrt and A.M. Gomaa, (2006). Performance of Thompson seedless grapevine as influenced by organic fertilizer, humic acid and biofertilizers under sandy soil conditions. Research Journal of Agriculture and Biological Sciences, 2(6): 467-471.

Sen, N.P. and B.D. Donaldson, (1978). Improved colorimetric method for determining nitrate and nitrite. Food J. Assoc. of Anal. Chem., 16: 13891395.

Wilde, S.A.; R.B. Corey; J.G. Layer and G.K. Voigt, (1985). Soil and Plant Analysis for Tree Culture, pp. 1-142. Published by Mohan Primlani, Oxford, IBH, Publishing Co., New Delhi. 